\title{
Optimization and validation of bioanalytical SPE - HPLC method for the simultaneous determination of carbamazepine and its main metabolite, carbamazepine-10, 11-epoxide, in plasma
}

\author{
Jasmina Tonic - Ribarska ${ }^{1 *}$, Zoran Sterjev ${ }^{2}$, Emilija Cvetkovska ${ }^{3}$, Igor Kuzmanovski \\ Gordana Kiteva ${ }^{3}$, Ljubica Suturkova ${ }^{2}$, Suzana Trajkovic - Jolevska ${ }^{1}$ \\ ${ }^{1}$ Institute of Applied Chemistry and Pharmaceutical Analysis, Faculty of Pharmacy, University "Ss Cyril and Methodius", \\ Skopje, Macedonia \\ ${ }^{2}$ Institute of Pharmaceutical Chemistry, Faculty of Pharmacy, University "Ss Cyril and Methodius", Skopje, Macedonia \\ ${ }^{3}$ Clinic of Neurology, Faculty of Medicine, University "Ss Cyril and Methodius", Skopje, Macedonia
}

Received: December 2011; Accepted: March 2012

\begin{abstract}
Carbamazepine is widely used as an antiepileptic drug in the treatment of partial and generalized tonic-clonic seizures. Carbamazepine 10,11-epoxide is the most important metabolite of carbamazepine, because it is a pharmacologically active compound with anticonvulsant properties. According to that, the routine analysis of carbamazepine 10,11-epoxide along with carbamazepine may provide optimal therapeutic monitoring of carbamazepine treatment.

The aim of this study was to optimize and validate a simple and reliable solid - phase extraction method followed by RP-HPLC for the simultaneous determination of plasma levels of carbamazepine and carbamazepine-10,11-epoxide, in order to assure the implementation of the method for therapeutic monitoring.

The extraction of the analytes from the plasma samples was performed by means of a solid-phase extraction procedure. The separation was carried out on a reversed-phase column using isocratic elution with acetonitrile and water $(35: 65, \mathrm{v} / \mathrm{v})$ as a mobile phase. The temperature was $30^{\circ} \mathrm{C}$ and UV detection was set at $220 \mathrm{~nm}$.

The extraction yield values were more than $98 \%$ for all analytes, measured at four concentration levels of the linear concentration range. The method displayed excellent selectivity, sensitivity, linearity, precision and accuracy. Stability studies indicate that stock solutions and plasma samples were stabile under different storage conditions at least during the observed period.

The method was successfully applied to determine the carbamazepine and carbamazepine-10,11-epoxide in plasma of epileptic patients treated with carbamazepine as monotherapy and in polytherapy.

In conclusion, the proposed method is suitable for application in therapeutic drug monitoring of epileptic patients undergoing treatment with carbamazepine.
\end{abstract}

Key words: carbamazepine, carbamazepine 10, 11-epoxide, plasma, solid-phase extraction, high-performance liquid chromatography, validation

\section{Introduction}

Carbamazepine (CBZ) (5-H-dibenze $[b, f]$ azepine-5carboxamide), a tricyclic lipophilic compound is a first line antiepileptic drug used in the treatment of partial and gen-

\footnotetext{
*jasminatonic@yahoo.com ; jato@ff.ukim.edu.mk
}

eralized tonic-clonic seizures. The main metabolic pathway of CBZ is epoxidation, which is catalyzed primarily by the cytochrome P450 enzyme CYP3A4 and results in the formation of carbamazepine-10,11-epoxide (CBZ-EP). From a clinical standpoint, CBZ-EP is the most important of the 33 metabolites of CBZ that have been isolated, because it is a pharmacologically active compound with anticonvulsant properties, as its parent compound (Sillanpaa 
et al., 2009).

Carbamazepine is highly bound $(75 \%$ to $80 \%)$ to plasma proteins, including albumin and $\alpha_{1}$-acid glycoprotein, while the epoxide binding is less strong $(50 \%$ to $60 \%$ bound). Since, the epoxide has a greater percentage in the free form (pharmacologically active fraction) and is equipotent to the parent drug, epoxide is assumed that contributes significantly to both therapeutic and adverse effects (Sillanpaa et al., 2009; Potter and Donnelly, 1998).

CBZ is usually administered at oral daily doses ranging from 400 to $1600 \mathrm{mg}$, which result in CBZ plasma concentrations in therapeutic range of $4-12 \mu \mathrm{g} / \mathrm{ml}$. With monotherapy of CBZ, the steady-state of CBZ-EP plasma concentration is equivalent to $20 \%-25 \%$ of the parent drug (Sillanpaa et al., 2009; Shen et al., 2001; Liu and Delgado, 1999).

Carbamazepine has a narrow therapeutic index, and the relationship between dose and plasma concentrations of carbamazepine may be unpredictable because of differences in genetics, age, gender, absorption, autoinduction and disease state between individuals. Also, the presence of numerous clinically significant drug interactions supports the need of using therapeutic monitoring of carbamazepine as an essential tool in designing a safe and effective therapeutic regimen for patients with epilepsy (Sillanpaa et al., 2009; Patsalos et al., 2008).

CBZ-EP was not routinely measured, though there were patients for whom high concentrations of this metabolite could be responsible for otherwise unexplained toxicity (Patsalos et al., 2008).

Therefore, the routine analysis of CBZ-EP along with CBZ may provide optimal therapeutic monitoring of CBZ treatment (Potter and Donnelly, 1998).

Most commonly applied methods for the routine monitoring of $\mathrm{CBZ}$ alone in plasma were commercial reagentbased techniques like as fluorescence polarization immunoassay (FPIA) and enzyme multiplied immunoassay technique (EMIT), especially in clinical settings (Kang et al., 2011). However, the antibodies used in these procedures, may sometimes cross-react with CBZ metabolites, leading to an overestimation of CBZ plasma levels, and to the lower specificity of the immunoassays (Kang et al., 2011; Eadie, 1998; Wilson et al., 1992).

A number of HPLC methods for simultaneous determination of CBZ and its metabolites in plasma have been published, using pretreatment techniques such as liquidliquid extraction (Oh et al., 2006; Moreno et al., 2003; Matar et al., 1999; Pienimaki et al., 1995; Miller and Vranderick, 1993), solid-phase extraction (Vermeij and Edelbroek, 2007; Mandrioli et al., 2001), deproteinization (Leite et al., 2009; Yoshida et al., 2006) and stir bar-sorptive extraction (Querioz et al., 2008). However, with some of these techniques the obtained extraction yields were not satisfactory, most of them were time-consuming, some required expensive instrument, rendering them not appropriate for routine drug monitoring. Deproteinization is simple, fast and costless technique, but offers minimal selectivity and sample cleanup as it only removes gross levels of protein from a sample prior to analysis. Oh et al. (2006) described a liquid - liquid extraction with methyl tert- butyl ether as sample pretreatment for simultaneous determination of CBZ and CBZ-EP in plasma. Even though the method showed excellent sensitivity, the extraction recoveries for CBZ-EP were less than $90 \%$, the analysis was time-consuming, and also, the chromatographic run was $30 \mathrm{~min}$. Another method for simultaneous determination of CBZ and CBZ-EP in plasma (along with phenytoin and phenobarbital) was described by Queiroz et al. (2008). They developed a stir bar-sorptive extraction, but this procedure required a very long analysis time (100 $\mathrm{min})$, expensive instruments, and the analysis was cumbersome.

LC-MS methods (Sener et al., 2007; Zhu et al., 2005; Van Rooyen et al., 2002) have also been reported for the determination of CBZ and its metabolites in biological fluids, but although they provide improved sensitivity and specificity compare with other analytical methods, MS procedures were more sophisticated and more expensive than HPLC-UV.

Therefore, HPLC with UV detection was the method of choice for the simultaneous monitoring of $\mathrm{CBZ}$ and CBZ-EP in biological fluids, after suitable pretreatment.

The aim of this study was to optimize and validate a simple and reliable solid - phase extraction method followed by RP-HPLC with UV detection for the simultaneous determination of plasma levels of carbamazepine and its main metabolite, carbamazepine 10, 11-epoxide, in order to obtain results of adequate quality and reliability to assure the implementation of the proposed bioanalytical method for the therapeutic monitoring of carbamazepine and its active metabolite.

\section{Material and methods}

\section{Chemicals and solutions}

Carbamazepine (CBZ), its metabolite carbamazepine10,11-epoxide (CBZ-EP) and nitrazepam used as the internal standard,(IS), were purchased from Sigma-Aldrich (St. Luis, MO, USA). Methanol and acetonitrile, HPLC grade, were obtained from Merck (Darmstadt, Germany). For all analysis HPLC grade water purified with a TKA_LAB Reinstwasser system (Niederelbert, Germany) was used. OASIS ${ }^{\circledR}$ HLB cartridges $(30 \mathrm{mg} / 1 \mathrm{~mL})$ used for the solid-phase extraction (SPE) procedure were supplied by Waters (Milford, MA, USA).

Stock solutions of CBZ $(500 \mu \mathrm{g} / \mathrm{ml})$, CBZ-EP (200 $\mu \mathrm{g} / \mathrm{ml})$ and the IS $(500 \mu \mathrm{g} / \mathrm{ml})$ were prepared by dissolving each compound in methanol. The stock solutions were stable for at least 3 months stored at $2-8{ }^{\circ} \mathrm{C}$. Working solutions were prepared daily from stock solutions by dilution with purified water. 


\section{Apparatus and chromatographic conditions}

The assay was carried out on Agilent 1100 HPLC system equipped with a vacuum degasser (G1322A Degasser), quaternary pump (G1311A QuatPump), autosampler (G1313A ALS), column compartment (G1316A COLCOM), diode array detector (G1315B DAD), and ChemStation for LC 3D software for data handling (Wilmington, DE).

Separation was performed on a reversed-phase column

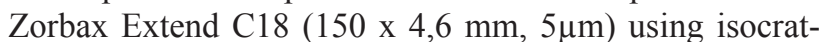
ic elution with acetonitrile and water $(35: 65, \mathrm{v} / \mathrm{v})$ as a mobile phase, at a flow rate of $1 \mathrm{ml} / \mathrm{min}$. The temperature was $30^{\circ} \mathrm{C}$, volume of injection $20 \mu \mathrm{l}$ and UV detection was set at $220 \mathrm{~nm}$.

\section{Human plasma sampling}

Plasma samples from both, healthy volunteers (drug - free plasma for the method validation) and from the epileptic patients undergoing chronic CBZ therapy, were obtained from Clinic of Neurology, Faculty of Medicine, University "Ss Cyril and Methodius", Skopje. The participation of each subject was voluntary and could be cancelled by any individual at any time during this study (according to the Helsinki II declaration). The Ethics Committee at the Faculty of Pharmacy and the Faculty of Medicine, Ss. Cyril and Methodius University - Skopje, approved the research protocol for this study and all volunteers signed the Study Informed Consent form.

Since CBZ has a relatively short half -life, sampling time in relation to dose ingestion was important for the interpretation of the drug concentration. Ideally, blood samples for TDM of CBZ should be drawn before the morning dose (Sillanpaa et al., 2009). Thus, blood samples were collected at $08.00 \mathrm{~h}$ in the morning, just before the first daily drug administration, into heparinised tubes (8-10 IU heparin $/ \mathrm{ml}$ blood), and centrifuged at $3000 \mathrm{rpm}$ for $10 \mathrm{~min}$. The supernatant plasma was transferred into test tubes and frozen at $-20{ }^{\circ} \mathrm{C}$ until analysis.

\section{Solid-phase extraction procedure (SPE)}

Prior to analysis, plasma samples were thawed and allowed to equilibrate at room temperature. To $250 \mu 1$ of epileptic patient plasma, $200 \mu \mathrm{l}$ ultrapure water and $50 \mu \mathrm{l}$ of IS solution $(5 \mu \mathrm{g} / \mathrm{ml})$ were added and the mixture was vortex-mixed for $30 \mathrm{~s}$.

The extraction of the analytes from the plasma samples was performed by means of a solid-phase extraction (SPE). For this purpose, OASIS ${ }^{\circledR}$ HLB cartridges $(30 \mathrm{mg} / 1 \mathrm{ml})$ were used. The SPE procedure was carried out according to the following steps: a) conditioning with $1 \mathrm{ml}$ methanol; b) equilibration with $1 \mathrm{ml}$ water; c) loading the plasma sample (of patients as described above and for validation purpose as described under the section Calibration curves); d) washing with $1 \mathrm{ml} \mathrm{5 \%} \mathrm{methanol.} \mathrm{Cartridge} \mathrm{dry-}$ ing for $30 \mathrm{~s}$ at - $20 \mathrm{kPa}$; e) elution with $500 \mu \mathrm{l}$ methanol. $20 \mu \mathrm{l}$ of the eluate was injected into the HPLC system.

\section{Bioanalytical method validation}

Method validation was conducted following the recommendations for validation of bioanalytical methods of EMA guideline (EMA, 2009).

According to the guideline, a complete method validation should be performed for any analytical method, new or based upon literature.

\section{Selectivity}

Selectivity was assessed by comparing the chromatograms of drug-free plasma (blank plasma) from six sources and those obtained from plasma samples spiked with analytes and internal standard.

\section{Calibration curves}

The calibration standards consist of drug free plasma samples spiking with known concentration of the analyte. Aliquots of $50 \mu \mathrm{l}$ of analytes working solutions (CBZ and CBZ-EP) at 7 different concentrations, $50 \mu \mathrm{l}$ of IS working solution, and $100 \mu \mathrm{l}$ ultrapure water were added to 250 $\mu \mathrm{l}$ of blank plasma. The resulting plasma concentrations were: $0.25 \mu \mathrm{g} / \mathrm{ml}, 0.5 \mu \mathrm{g} / \mathrm{ml}, 1.0 \mu \mathrm{g} / \mathrm{ml}, 5.0 \mu \mathrm{g} / \mathrm{ml}, 10.0$ $\mu \mathrm{g} / \mathrm{ml}, 20.0 \mu \mathrm{g} / \mathrm{ml}$ and $25.0 \mu \mathrm{g} / \mathrm{ml}$ for CBZ and $0.1 \mu \mathrm{g} / \mathrm{ml}$, $0.25 \mu \mathrm{g} / \mathrm{ml}, 0.5 \mu \mathrm{g} / \mathrm{ml}, 1.0 \mu \mathrm{g} / \mathrm{ml}, 2.5 \mu \mathrm{g} / \mathrm{ml}, 5 \mu \mathrm{g} / \mathrm{ml}$ and $10 \mu \mathrm{g} / \mathrm{ml}$ for CBZ-EP, containing the IS at constant concentration of $5 \mu \mathrm{g} / \mathrm{ml}$. Calibration standards were subjected to the SPE procedure and injected into the HPLC. The obtained analyte - IS peak area ratios were plotted versus the respective analyte concentrations and the calibration curves for CBZ and CBZ-EP were constructed by means of the least-squares method.

\section{Accuracy and precision}

The quality control samples (QC samples) were used to assess the accuracy and precision of the method. Four levels of QC samples were prepared at the concentrations of $0.25 \mu \mathrm{g} / \mathrm{ml}$ (lower limit of quantitation), $1.0 \mu \mathrm{g} / \mathrm{ml}$ (low QC sample), $5.0 \mu \mathrm{g} / \mathrm{ml}$ (medium QC sample) and $20.0 \mu \mathrm{g} /$ $\mathrm{ml}$ (high QC sample) for CBZ and at the concentrations of $0.1 \mu \mathrm{g} / \mathrm{ml}$ (lower limit of quantitation), $0.5 \mu \mathrm{g} / \mathrm{ml}$ (low QC sample), $2.5 \mu \mathrm{g} / \mathrm{ml}$ (medium QC sample) and $5.0 \mu \mathrm{g} / \mathrm{ml}$ (high QC sample) for CBZ-EP, in same way as described above for the calibration standards. Accuracy and precision were evaluated for the values of the QC samples obtained within a single run (the within run) and in different runs (the between-run). Within-run accuracy and precision were determined for five samples per concentration level at LLOQ, low, medium and high QC samples in a single run. Between-run accuracy and precision were assessed by 
five determination per concentration per run at LLOQ, low, medium and high QC samples from three runs analyzed on two different days.

\section{Recovery}

Extraction yields were assessed at four concentration levels corresponding to the lower limit, low, medium and high point of each calibration curve (i.e. plasma concentration of $0.25 \mu \mathrm{g} / \mathrm{ml}, 1.0 \mu \mathrm{g} / \mathrm{ml}, 5.0 \mu \mathrm{g} / \mathrm{ml}$ and $20 \mu \mathrm{g} / \mathrm{ml}$ for $\mathrm{CBZ}$, and $0.1 \mu \mathrm{g} / \mathrm{ml}, 0.5 \mu \mathrm{g} / \mathrm{ml}, 2.5 \mu \mathrm{g} / \mathrm{ml}$ and $5.0 \mu \mathrm{g} / \mathrm{ml}$ for CBZ-EP).

\section{Stability}

Stability tests were performed on three replicates of low and high QC samples after $24 \mathrm{~h}$ at room temperature (short term stability), after three freeze-thaw cycles, autosampler stability for $12 \mathrm{~h}$, and after 90 days on samples stored at $-20{ }^{\circ} \mathrm{C}$ (long term stability). Stability tests were also performed on stock solutions of analytes after $24 \mathrm{~h}$ at room temperature and after 3 months at $2-8^{\circ} \mathrm{C}$.

\section{Results and discussion}

\section{Optimization of chromatographic condition}

Many studies were conducted with the aim of developing new bioanalytical methods or improve existing methods for TDM of antiepileptic drugs.

In order to establish the chromatographic conditions for the determination of CBZ and CBZ-EP in plasma, number of literature data were reviewed and many experiments were made. During the optimization of the chromatographic conditions different mobile phases (different types of organic solvents and different organic to aqueous phase ratio) were evaluated, in order to ascertain whether a faster separation is possible, which is an important fact for routine control. The experiments were made using the mixture of methanol/water, the mixture of methanol/acetonitrile/ water, and the mixture of acetonitrile/water, in different ratio compared the organic and water phase.

The best results of good separation of all analytes were obtained with the mixture of acetonitrile-water (35:65, $\mathrm{v} / \mathrm{v}$ ), using a Zorbax Extend C18 (150 x 4,6 mm, $5 \mu \mathrm{m})$ column at temperature of $30^{\circ} \mathrm{C}$ and flow rate of $1 \mathrm{ml} / \mathrm{min}$.

Under these chromatographic conditions, CBZ, its active metabolite CBZ-EP and the internal standard were baseline separated in less than $7 \mathrm{~min}$, in contrast to $30 \mathrm{~min}$ reported by $\mathrm{Oh}$ et al. (2006) and $20 \mathrm{~min}$ reported by Leite et al. (2009).

\section{Solid-phase extraction (SPE) procedure}

Application of a SPE technique was chosen for the sample pre-treatment, because it makes sample preparation more feasible, simple and accurate, less polluting than the liquid-liquid extraction, and allows high extraction yields with good selectivity.

Mandrioli et al. (2001) performed a SPE procedure for extraction of CBZ and its five metabolites from human plasma using tetrahydrofuran for elution. However, the usage of this strong solvent caused peak broadening and interference, so its completely elimination from injection mixture was necessary.

In order to simplify the SPE procedure and considering the good solubility of CBZ and CBZ-EP in methanol, elution of the analytes from the cartridge was performed with methanol (instead of tetrahydrofuran), thus making the method less prone to interference. Furthermore, the last step of procedure, the dryness of the eluate, was avoided.

The optimized SPE procedure included loading the conditioned cartridge with $250 \mu \mathrm{l}$ of plasma, washing with $1 \mathrm{ml}$ of $5 \%$ methanol and eluting the analytes with $500 \mu 1$ of methanol. The extraction yield values were higher than 98\% for CBZ and CBZ-EP, which were better than those reported in papers using liquid-liquid extraction (Oh et al., 2006) or SPE procedure (Mandrioli et al., 2001). The chromatograms of a blank plasma sample and of a blank plasma spiked with standard solutions of analytes and IS, subjected to the described SPE procedure, were presented in Fig. 1. No interference from endogenous plasma components was present. Moreover, the SPE procedure gave excellent results when was applied to plasma samples of patients undergoing chronic treatment with CBZ, both in monotherapy and polytherapy. No interfering peaks due to the co-administered drugs were eluted at the retention times of analytes (Fig. 3.).

\section{Bioanalytical method validation}

Validation of the bioanalytical method is a compulsory step to estimate the ability of the developed method to provide accurate results for its routine application (Rozet et al., 2011).

\section{Selectivity}

The selectivity of the method was assessed by analyzing six different drug free plasma samples and drug free plasma spiked with CBZ, CBZ-EP and nitrazepam as internal standard. The chromatograms of blank plasma and blank plasma spiked with analytes were presented in Fig.1. The retention times for CBZ, CBZ-EP and IS were $2.8 \mathrm{~min}$, $4.7 \mathrm{~min}$ and $6.6 \mathrm{~min}$, respectively. No interfering peaks for endogenous compounds were observed in the retention times of CBZ, CBZ-EP and IS.

\section{Calibration curves}

Prior to carrying out the validation of the bioanalytical method the concentration range should be justified based on scientific information. The range should be covered by 
a)

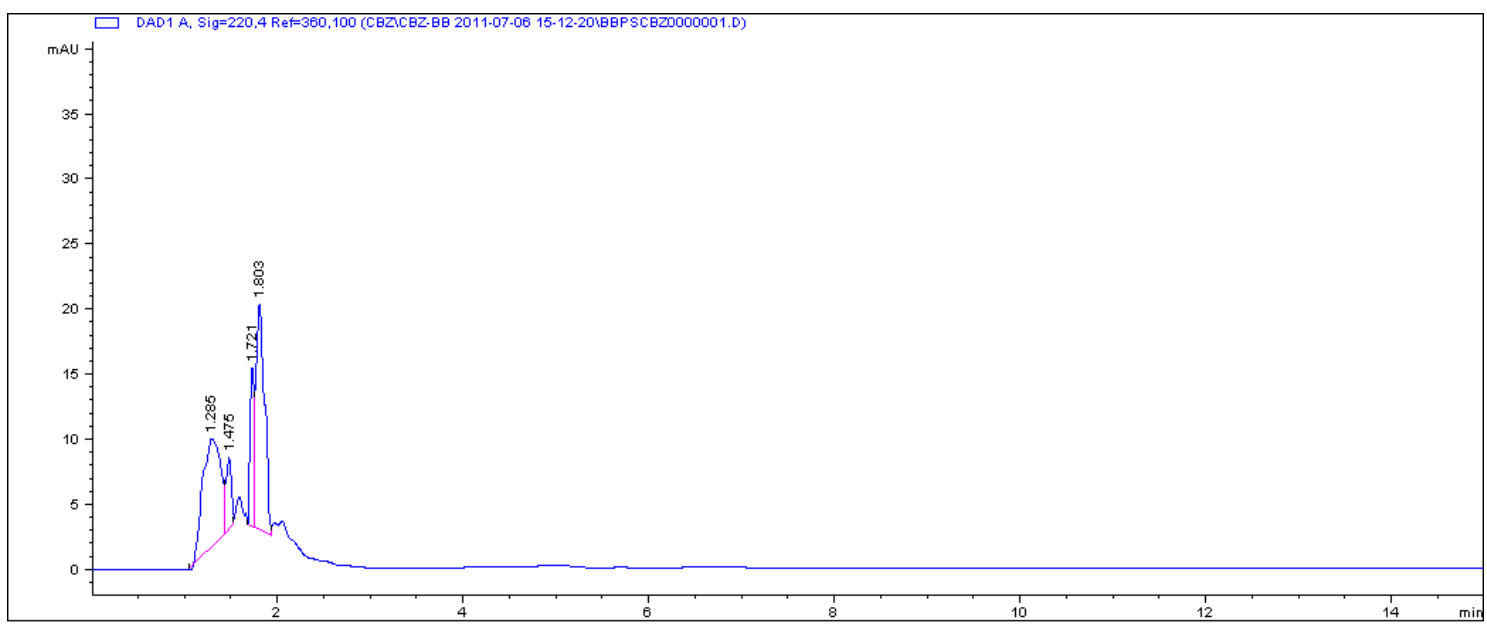

$\square$ DAD1 A, Sig=220,4 Ref=360,100 (CBZCACB-8B 2011-07-06 15-12-2018BPSCBZ0000000.D)

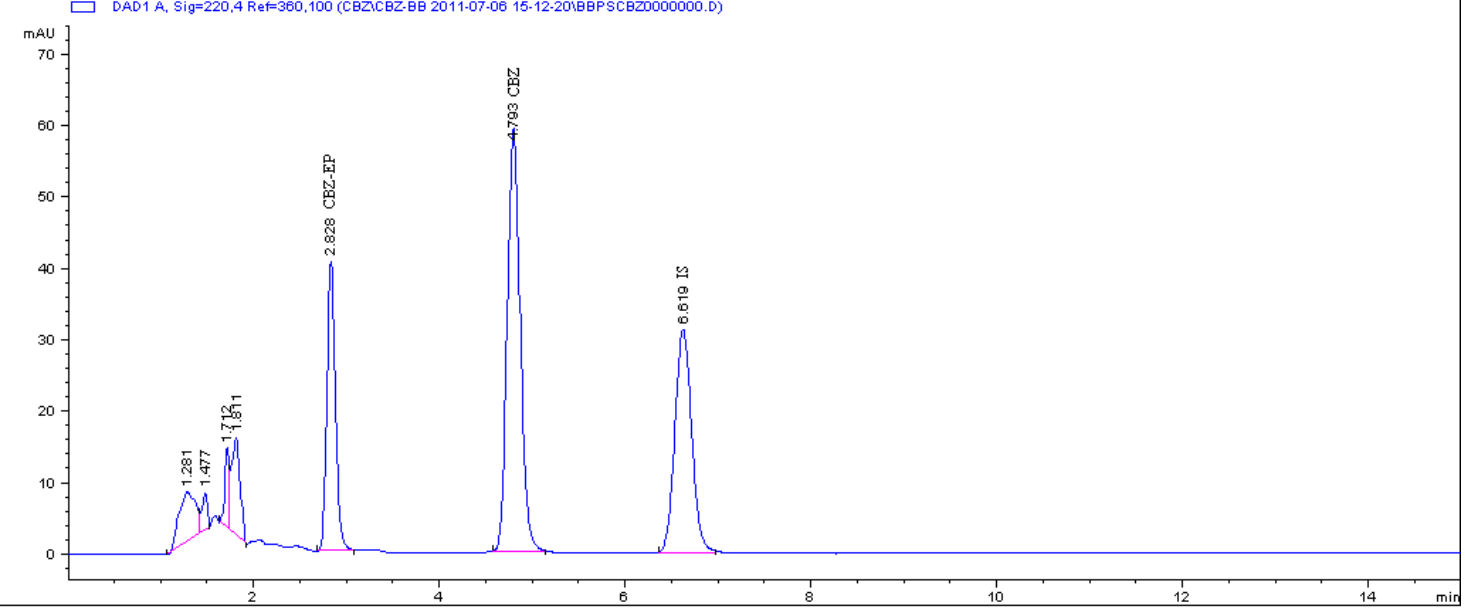

b)

Fig. 1. Chromatograms of: a) blank plasma, and b) blank plasma spiked with $5.0 \mu \mathrm{g} / \mathrm{ml} \mathrm{CBZ,} 2.5 \mu \mathrm{g} / \mathrm{ml} \mathrm{CBZ-EP}$ and $5.0 \mu \mathrm{g} / \mathrm{ml}$ nitrazepam (IS), after the SPE procedure.

the calibration curve range, defined by the lower limit of quantitation (LLOQ) and the upper limit of quantitation (ULOQ). LLOQ is the lowest amount of analyte in a sample (plasma) which can be quantified reliably and should be adapted to expected concentrations and to the aim of the study.

The acceptable criterion for each standard concentration was $\pm 15 \%$ of the nominal value, except for the LLOQ which was $\pm 20 \%$.

Seven-point calibration curves were set up for CBZ and CBZ-EP within the concentration range of $0.25-20.0$ $\mu \mathrm{g} / \mathrm{ml}$ for CBZ and $0.1-10.0 \mu \mathrm{g} / \mathrm{ml}$ for CBZ-EP. The calibration curves were linear over the defined concentration ranges according to the levels of each compound expected in patients' plasma samples, including LLOQ.

The regression equations were $\mathrm{y}=154.87 \mathrm{x}-19.828$ with a coefficient of determination $\mathrm{r}^{2}=0.9989$ for CBZ and $y=117.96 x+1.219$ with a coefficient of determination $\mathrm{r}^{2}=0.9991$ for CBZ-EP.

\section{Accuracy and precision}

The within - run and between - run accuracy and precision were shown in Table 1. All the results of the tested samples were within recommended limits. Within-run assay precision ranged from $0.6 \%$ to $1.2 \%$ for $\mathrm{CBZ}$ and from $0.7 \%$ to $2.0 \%$ for CBZ-EP, while within-run assay accuracy ranged from $98.4 \%$ to $101.3 \%$ and $97.0 \%$ to $100.6 \%$, for CBZ and CBZ-EP, respectively. The between-run precision and accuracy, ranged from $0.9 \%$ to $2.2 \%$ and $97.9 \%$ to $102.1 \%$ for CBZ, while for CBZ-EP the ranges were $0.9 \%$ to $3.1 \%$ and $96.7 \%$ to $102.7 \%$, respectively.

\section{Recovery (Extraction yield)}

Recovery describes the extraction efficiency of the analytical process. The recovery was calculated by comparison of the peak areas of analytes obtained from the SPE processed blank plasma sample previously spiked with analytes versus peak areas obtained from a post - extracted spiked blank plasma sample, which represent $100 \%$ recovery (Matuszewski et al., 2003). 
Table 1. Accuracy and precision of carbamazepine and carbamazepine-10,11-epoxide in human plasma

\begin{tabular}{|c|c|c|c|c|c|}
\hline \multirow{2}{*}{ Analyte } & \multirow{2}{*}{$\begin{array}{l}\text { Nominal conc. } \\
\qquad(\mu \mathrm{g} / \mathrm{ml})\end{array}$} & \multicolumn{2}{|c|}{ Within-run assay $(n=5)$} & \multicolumn{2}{|c|}{ Between-run assays $(n=30)$} \\
\hline & & accuracy (\%) & precision $(\mathrm{CV} \%)$ & accuracy (\%) & precision $(\mathrm{CV} \%)$ \\
\hline \multirow[t]{4}{*}{$\mathrm{CBZ}$} & 20.0 & 99.2 & 1.2 & 98.6 & 2.2 \\
\hline & 5.0 & 99.5 & 0.8 & 98.5 & 1.1 \\
\hline & 1.0 & 101.3 & 1.0 & 102.1 & 0.9 \\
\hline & 0.25 & 98.4 & 0.6 & 97.9 & 1.8 \\
\hline \multirow[t]{4}{*}{ CBZ-EP } & 5.0 & 100.6 & 1.1 & 100.9 & 1.0 \\
\hline & 2.5 & 99.1 & 2.0 & 97.6 & 3.1 \\
\hline & 0.5 & 97.3 & 0.8 & 96.7 & 1.7 \\
\hline & 0.1 & 97.0 & 0.7 & 102.7 & 0.9 \\
\hline
\end{tabular}

Table 2. Recoveries of carbamazepine and carbamazepine-10,11-epoxide from plasma $(\mathrm{n}=5)$

\begin{tabular}{cccc}
\hline \hline Analyte & $\begin{array}{c}\text { Nominal conc. } \\
(\mu \mathrm{g} / \mathrm{ml})\end{array}$ & $\begin{array}{c}\text { Found conc. } \\
(\mu \mathrm{g} / \mathrm{ml})\end{array}$ & $\begin{array}{c}\text { Recovery } \\
(\%)\end{array}$ \\
\hline CBZ & 20.0 & 19.70 & 98.5 \\
& 5.00 & 4.98 & 99.6 \\
& 1.00 & 0.99 & 99.0 \\
CBZ-EP & 0.25 & 0.247 & 98.8 \\
& 5.00 & 4.98 & 99.6 \\
& 2.50 & 2.48 & 99.2 \\
& 0.50 & 0.497 & 99.4 \\
\end{tabular}

Table 3. Stability of carbamazepine and carbamazepine-10,11-epoxide in human plasma under various conditions ( $\mathrm{n}=3$ )

\begin{tabular}{|c|c|c|}
\hline $\begin{array}{l}\text { Nominal concentration }(\mu \mathrm{g} / \mathrm{ml}) \\
\text { CBZ / CBZ-EP }\end{array}$ & $\begin{array}{c}\text { Initial concentration } \\
\mathrm{t}=0 \mathrm{~min}(\mu \mathrm{g} / \mathrm{ml}) \\
\mathrm{CBZ} / \mathrm{CBZ}-\mathrm{EP}\end{array}$ & 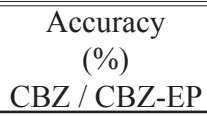 \\
\hline \multicolumn{3}{|l|}{$\begin{array}{l}\text { Short term stability } \\
\text { ( } 24 \mathrm{~h} \text { at room temperature) }\end{array}$} \\
\hline $\begin{array}{c}1.0 / 0.5 \\
20.0 / 5.0\end{array}$ & $\begin{array}{c}1.02 / 0.51 \\
19.98 / 5.03\end{array}$ & $\begin{array}{c}99.0 / 98.6 \\
101.2 / 99.3\end{array}$ \\
\hline \multicolumn{3}{|l|}{ Autosampler stability (after $12 \mathrm{~h}$ ) } \\
\hline $\begin{array}{l}1.0 / 0.5 \\
20.0 / 5.0\end{array}$ & $\begin{array}{c}1.01 / 0.51 \\
20.04 / 4.99\end{array}$ & $\begin{array}{l}97.1 / 96.0 \\
98.8 / 97.4\end{array}$ \\
\hline \multicolumn{3}{|l|}{ Three freeze-thaw cycles } \\
\hline $\begin{array}{c}1.0 / 0.5 \\
20.0 / 5.0\end{array}$ & $\begin{array}{c}1.02 / 0.49 \\
20.02 / 4.97\end{array}$ & $\begin{array}{l}94.8 / 93.2 \\
97.7 / 94.1\end{array}$ \\
\hline \multicolumn{3}{|l|}{$\begin{array}{l}\text { Long term stability } \\
\left(90 \text { days at }-20^{\circ} \mathrm{C}\right)\end{array}$} \\
\hline $\begin{array}{l}1.0 / 0.5 \\
20.0 / 5.0\end{array}$ & $\begin{array}{c}0.99 / 0.50 \\
19.89 / 5.10\end{array}$ & $\begin{array}{c}98.8 / 99.1 \\
100.6 / 99.3\end{array}$ \\
\hline
\end{tabular}

The extraction yields were evaluated at four concentration levels (LLOQ, low QC, medium QC and high QC sample) of the linear concentration range for both, $\mathrm{CBZ}$ and CBZ-EP. The obtained values were in the range of $98.5 \%$ 99.6\% for CBZ and 99.1\% - 99.7\% for CBZ-EP (Table 2), while the recovery value for IS was $98.9 \%$. These results indicate excellent recoveries for all analytes which means that the proposed SPE procedure is appropriate to be ap- plied to the determination of $\mathrm{CBZ}$ and its active metabolite in plasma taken from epileptic patients.

\section{Stability}

Stability experiments were performed through evaluation the stability of CBZ and CBZ-EP, and also IS stock 
solutions and plasma samples under different conditions. Stock solutions of analytes were stable at room temperature for $24 \mathrm{~h}$ (accuracy: $99.6 \%, 99.4 \%$ and $100.3 \%$ for CBZ, CBZ-EP and IS, respectively) and at $2-8{ }^{\circ} \mathrm{C}$ for 3 months (accuracy: 101.7\%, 98.3\% and 98.1\% for CBZ, CBZ-EP and IS, respectively). It was shown that the human plasma samples spiked with $\mathrm{CBZ}$ and CBZ-EP were stable after three freeze-thaw cycles, after $12 \mathrm{~h}$ in autosampler and at room temperature for $24 \mathrm{~h}$. The study indicated that the plasma samples could be stored at $-20^{\circ} \mathrm{C}$ for 90 days. The results of stability were presented in Table 3 .

The obtained results indicate that the analytes were stable under all storage conditions described above and that no stability related problems would be expected during the routine plasma sample analysis.

\section{Application to patient plasma}

The proposed method was applied to the simultaneous determination of CBZ and its active metabolite, CBZ$\mathrm{EP}$, in plasma samples taken from epileptic patients under chronic CBZ therapy (400 - $1200 \mathrm{mg} /$ day). The chromatogram of a plasma sample from a patient, who received $400 \mathrm{mg}$ /day of CBZ, taken $12 \mathrm{~h}$ after the last drug intake was reported in Fig. 2. By interpolation on the respective calibration curves, the following concentrations were ob-

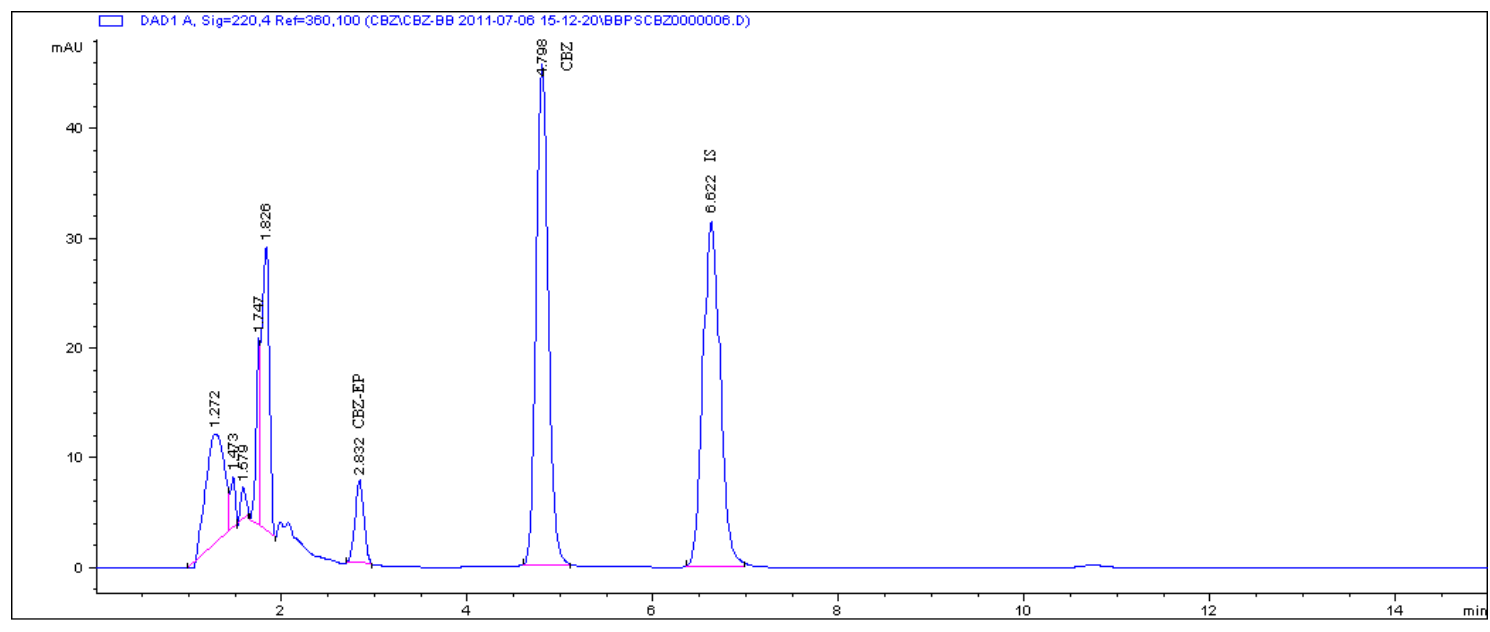

Fig. 2. Chromatogram of plasma sample from a patient treated with $400 \mathrm{mg} /$ day of CBZ, subjected to the developed SPE procedure.

Table 4. Results of analysis on patient plasma samples

\begin{tabular}{|c|c|c|c|c|c|}
\hline \multirow[b]{2}{*}{ Patient no. } & \multirow[b]{2}{*}{$\begin{array}{l}\text { Dosage } \\
\text { (mg/day) }\end{array}$} & \multirow[b]{2}{*}{ Co-administered drugs } & \multicolumn{3}{|c|}{ Determined concentration $(\mu \mathrm{g} / \mathrm{ml})$} \\
\hline & & & $\begin{array}{l}\text { FPIA method } \\
\text { CBZ }\end{array}$ & $\begin{array}{c}\text { HPLC method } \\
\text { CBZ }\end{array}$ & $\begin{array}{l}\text { HPLC method } \\
\text { CBZ-EP }\end{array}$ \\
\hline 1 & 400 & - & 4.96 & 4.69 & 0.92 \\
\hline 2 & 400 & - & 8.98 & 5.71 & 0.88 \\
\hline 3 & 600 & - & 6.83 & 6.54 & 1.11 \\
\hline 4 & 400 & - & 8.04 & 7.32 & 0.74 \\
\hline 5 & 400 & - & 4.26 & 4.02 & 0.40 \\
\hline 6 & 400 & - & 4.73 & 4.71 & 0.55 \\
\hline 7 & 800 & - & 7.05 & 6.49 & 1.00 \\
\hline 8 & 400 & - & 4.73 & 4.02 & 0.81 \\
\hline 9 & 800 & Levetiracetame & 8.09 & 7.55 & 1.33 \\
\hline 10 & 800 & - & 6.93 & 6.34 & 0.83 \\
\hline 11 & 800 & Phenobarbital & 3.31 & 2.89 & 0.67 \\
\hline 12 & 600 & - & 8.27 & 7.52 & 1.92 \\
\hline 13 & 1200 & Lamotrigine & 8.51 & 8.06 & 1.78 \\
\hline 14 & 800 & Valproate & 10.40 & 7.90 & 2.90 \\
\hline 15 & 1200 & Levetiracetame, Lamotrigine & 7.73 & 6.37 & 1.45 \\
\hline 16 & 800 & - & 6.86 & 6.14 & 1.09 \\
\hline 17 & 400 & - & 4.66 & 4.65 & 0.92 \\
\hline 18 & 1200 & Levetiracetame, Lamotrigine, Topiramate & 8.27 & 5.59 & 0.95 \\
\hline 19 & 400 & - & 4.73 & 4.05 & 1.14 \\
\hline 20 & 800 & - & 7.80 & 7.01 & 1.68 \\
\hline
\end{tabular}




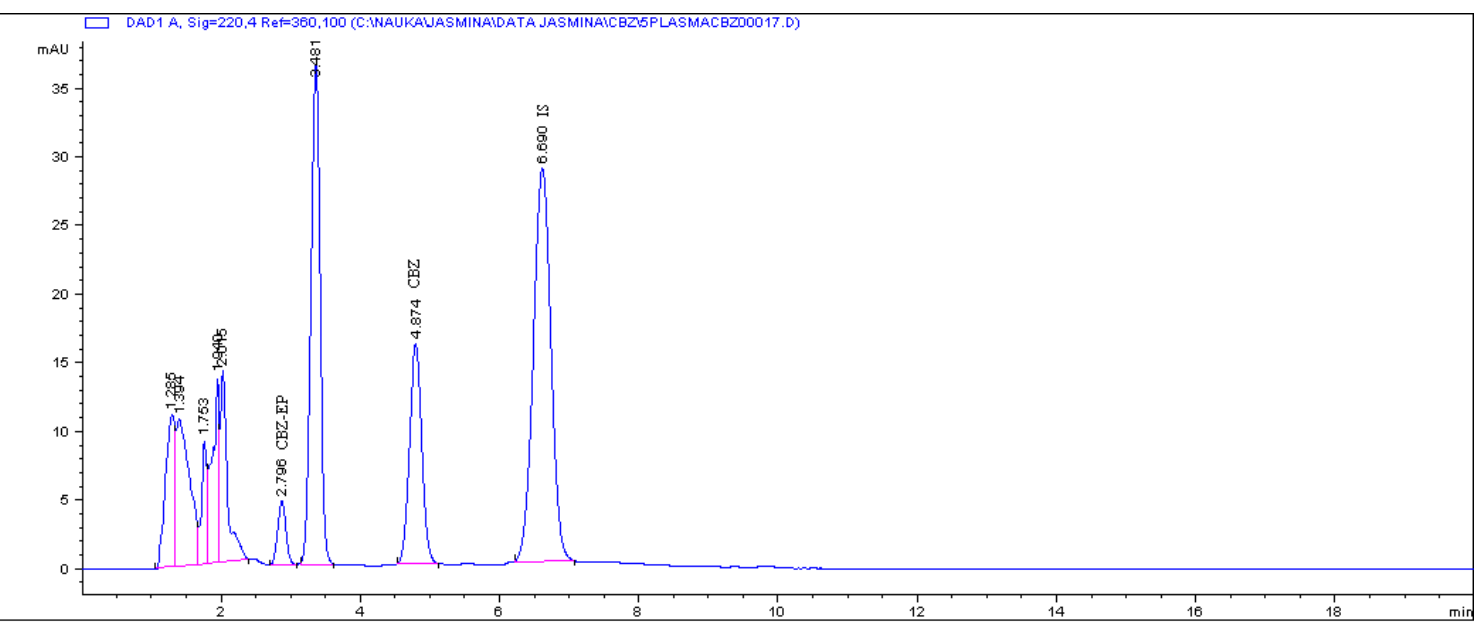

a)

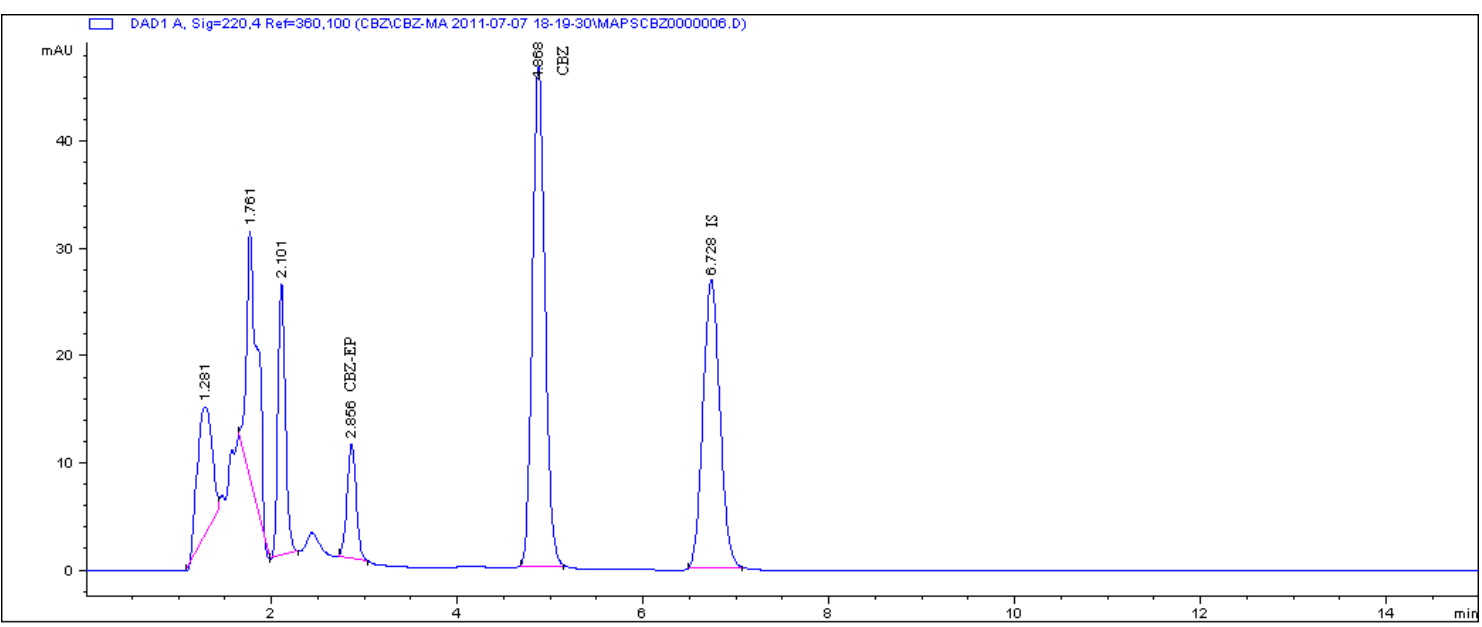

b)

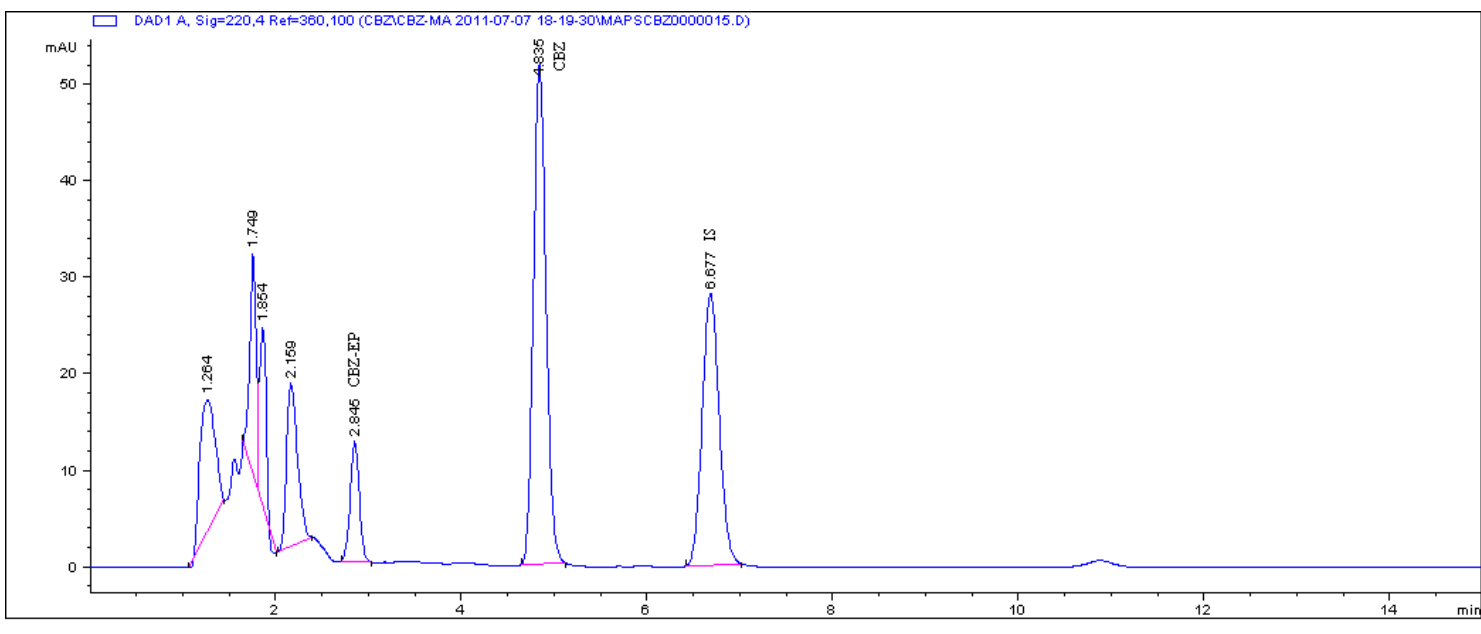

c)

Fig. 3. Chromatograms of plasma samples from patients treated with: a) carbamazepine and phenobarbital; b) carbamazepine and valproate; c) carbamazepine, lamotrigine, topiramate and levetiracetam, subjected to the developed SPE procedure.

tained: $4.69 \mu \mathrm{g} / \mathrm{ml}$ for CBZ and $0.92 \mu \mathrm{g} / \mathrm{ml}$ for CBZ-EP. The results obtained from the assays on 20 patient plasma samples were reported in Table 4.
In this table the CBZ plasma concentrations obtained with the proposed HPLC method were also compared with those obtained from the same samples by FPIA method pre- 
formed in the laboratory at Clinic of Neurology, Faculty of Medicine, Skopje. Statistical analysis was performed using GraphPad Prism software (version 5.0). A significant linear correlation was obtained $(r=0.8898, p<0.0001)$. Comparison of the values by paired $t$ - test indicated that the FPIA concentrations were significantly greater $(p<0.001)$ than those obtained by HPLC method. The probable reason for this was interference by CBZ metabolites, mainly by CBZ-EP, with FPIA technique (Kang et al., 2011; Wilson et al., 1992).

Given that epileptic patients are often treated with polytherapy, it was important to assess probable chromatographic interferences from potentially co-administered antiepileptic drugs. To evaluate the selectivity of proposed method, plasma samples taken from patients simultaneously treated with valproate, lamotrigine, topiramate, phenobarbital and levetiracetam (commonly prescribed drugs along with CBZ), were analysed. The chromatograms of plasma samples of patients treated with polytherapy (patient 11: phenobarbital along with CBZ; patient 14: valproate along with $\mathrm{CBZ}$, and patient 18: lamotrigine, topiramate and levetiracetam along with $\mathrm{CBZ}$ ) were presented in Fig.3.

It was evident that no chromatographic interference from co-administered drugs were observed in the retention times of CBZ, CBZ-EP and IS, hence the method could be applied for TDM of CBZ and CBZ-EP in patients undergoing chronic treatment with CBZ, either as monotherapy or in polytherapy with other antiepileptic drugs.

\section{Conclusion}

A simple and reliable bioanalytical HPLC method has been optimizated and validated for the simultaneous determination of carbamazepine and its active metabolite, carbamazepine-10, 11-epoxide in human plasma after solidphase extraction.

The SPE procedure applied gave excellent recovery values for carbamazepine and carbamazepine-10, 11-epoxide. All analytes were baseline separated in less than $7 \mathrm{~min}$.

The validation data demonstrate that the proposed bioanalytical method is selective, sensitive, linear, precise and accurate.

The method was successfully applied to separate and determine the CBZ and CBZ-EP in plasma obtained from epileptic patients treated with CBZ as monotherapy and in polytherapy.

According to all obtained results, it can be concluded that the proposed method is suitable for a reliable therapeutic drug monitoring of patients undergoing therapy with carbamazepine, both in monotherapy and in polytherapy. Since, it requires only $250 \mu \mathrm{l}$ of plasma for one complete analysis, the proposed method could be particularly advantageous when multiple blood sampling were needed, as in pharmacokinetic studies.

\section{References}

Eadie, M. J., 1998. Therapeutic drug monitoring-antiepileptic drugs. Br. J. Clin. Pharmacol. 46, 185-193.

European Medicines Agency. Guideline on validation of bioanalytical methods. Committee for Medicinal Products for Human Use (CHMP). 2009. http://www.ema.europa.eu/docs/ en_GB/document_library/Scientific_guideline/2009/12/ WC̄500018062.pdf

Kang , J., Park,Y., Kim, S., Kim, S., Jun, M., 2011. Modern methods for analysis of antiepileptic drugs in the biological fluids for pharmacokinetics, bioequivalence and therapeutic drug monitoring. Korean J. Physiol. Pharmacol. 15, 67-81.

Leite, C. E., Petersen, G. O., Lunardelli, A., Thiesen, F. V., 2009. A HPLC method for the determination of carbamazepine and carbamazepine 10,11-epoxide and its comparison with chemiluminescent immunoassay. Clin. Chem. Lab. Med. 47, 458-463.

Liu, H. and Delgado, M.R., 1999. Therapeutic drug concentration monitoring: Focus on anticonvulsants. Clin. Pharmacokinet. $36,453-470$.

Mandrioli, R., Albani, F., Casamenti, G., Sabbioni, C., Raggi, M. A., 2001. Simultaneous HPLC determination of carbamazepine and five of its metabolites in plasma of epileptic patients. J.Chromatogr. B. 762, 109-116.

Matar, K.M., Nicholls, P.J., Tekle, A., Bawazir, S.A., Al-Hassan, M.I., 1999. LC determination of six antiepileptic drugs and two metabolites in microsamples of human plasma. Ther. Drug Monit. 21, 559-566.

Matuszewski, B. K., Constanzer,M. L., Chavez-Eng, C. M., 2003. Strategies for the Assessment of Matrix Effect in Quantitative Bioanalytical Methods Based on HPLC-MS/ MS. Anal. Chem. 75, 3019-3030.

Miller, R.B., Vranderick, M., 1993. A validated HPLC method for the determination of carbamazepine and carbamazepine10,11-epoxide in human plasma. J.Liq.Chromatogr. 16, 1249-1261.

Moreno, J., Belmont, A., Jaimes, O., Santos, J.A., Lopez, G., Campos, M.G., Amancio, O., Perez, P., Heinze, G., 2004. Pharmacokinetic study of carbamazepine and its carbamazepine 10,11-epoxide metabolite in a group of female epileptic patients under chronic treatment. Arch. Med. Res. 35, 168-171.

Oh, E., Ban, E., Woo, J.S., Kim, C., 2006. Analysis of carbamazepine and its active metabolite carbamazepine10,11-epoxide, in human plasma using HPLC. Anal. Bioanal. Chem. 386, 1931-1936.

Patsalos, P. N., Berry, D. J., Bourgeois, B. F. D., Cloyd, J. C., Glauser, T. A., Johannessen, S. I., Leppik, I. E., Tomson, T., Patsalos, E. P., 2008. Antiepileptic drugs - best practice guidelines for therapeutic drug monitoring: A position paper by the subcommission on the therapeutic drug monitoring, ILAE Commission on Therapeutic Strategies. Epilepsia 49, 1239-1276.

Pienimaki, P., Fuchs, S., Isojarvi, J., Vahakangas, K., 1995. Improved detection and determination of carbamazepine and oxcarbazepine and their metabolites by high-performance liquid chromatography. J. Chromatogr. B. 673, 97-105.

Potter, J.M., Donnelly, A., 1998. Carbamazepine-10,11-epoxide in therapeutic drug monitoring. Ther. Drug Monit. 20, 652657. 
Queiroz, R.H.C., Bertucci, C., Malfara, W.R., Dreossi, S.A.C., Chaves, A.R., Valerio, D.A.R., Queiroz, M.E.C., 2008. Quantification of carbamazepine, carbamazepine-10,11epoxide, phenytoin and Phenobarbital in plasma samples by stir bar-sorptive extraction and liquid chromatography. J. Pharm. Biomed. Anal. 48, 428-434.

Rozet, E., Marini, R.D., Ziemons, E., Boulanger, B., Hubert, P., 2011. Advances in validation, risk and uncertainty assessment of bioanalytical methods. J. Pharm. Biomed. Anal. 55, 848858.

Sener, E., Korkmaz, O. T., Yeniceli, D., Dogrukol-Ak, D., Tuncel, M., Tuncel, N., 2007. Determination Of CBZ and its main metabolite CBZ-10,11-epoxide in rat brain microdialysate and blood using ESI-LC-MS (ion trap). Chromatographia 66, 31-36.

Shen, S., Elin, R. J., Soldin, S. J., 2001. Characterization of cross reactivity by carbamazepine-10,11-epoxide with carbamazepine assays. Clin. Biochem. 34, 157-158.

Silanpaa, M., Haataja, L., Tomson, T., Johannessen, S. I., 2009. Carbamazepine, in: Shorvon, S., Perucca, E., Engel, J. (Eds), The treatment of epilepsy, third ed. Blackwell Publishing LTD., Oxford, pp. 459-474.

Soldin, S. J., 1999. Free drug measurement. Arch. Pathol. Lab. Med. 123, 822-823.

Van Rooyen, G.F., Badenhorst, D., Swart, K.J., Hundt, H.K., Scanes, T., Hundt, A.F., 2002. Determination of carbamazepine and carbamazepine 10,11-epoxide in human plasma by tandem liquid chromatography-mass spectrometry with electrospray ionisation. J. Chromatogr. B Analyt. Technol. Biomed. Life. Sci. 25, 1-7.

Vermeij, T.A., Edelbroek, P.M., 2007. Robust isocratic HPLC method for simultaneous determination of seven antiepileptic drugs including lamotrigine, oxcarbamazepine and zonisamide in serum after SPE. J. Chromatogr. B. 857, 40-46.

Wilson, J. F., Tsanaclis, L. M., Perrett, J. E., Williams, J., Wicks, J. F. C., Richens, A., 1992. Performance of techniques for measurement of therapeutic drugs in serum. A comparison based on external quality assessment data. Ther. Drug Monit. 14, 98-106.

Yoshida, T., Imai, K., Motohashi, S., Hamano, S., Sato, M., 2006. Simultaneous determination of zonisamide, carbamazepine and carbamazepine-10,11-epoxide in infant serum by HPLC. J. Pharm. Biomed. Anal. 16, 1386-1390.

Zhu, Y., Chiang, H., Wulster-Radcliffe, M., Hilt, R., Wong, P., Kissinger, C.B., Kissinger, P.T., 2005. Liquid chromatography/tandem mass spectrometry for the determination of carbamazepine and its main metabolite in rat plasma utilizing an automated blood sampling system. J. Pharm. Biomed. Anal. 38, 119-125.

\title{
Оптимизација и валидација на биоаналитички SPE-HPLC метод за истовремено определување на карбамазепин и неговиот главен метаболит, карбамазепин-10,11-епоксид, во плазма
}

\author{
Јасмина Тониќ - Рибарска ${ }^{1 *}$, Зоран Стерјев², Емилија Цветковска \\ Игор Кузмановски ${ }^{3}$, Гордана Китева ${ }^{3}$, Љубица Шутуркова ${ }^{2}$, \\ Сузана Трајковиќ - Јолевска ${ }^{1}$
}

\begin{abstract}
${ }^{1}$ Институт за применета хемија и фармаџевтски анализи, Фармаџевтски факултет, Универзитет "Св Кирил и Методиј”, Скопје, Македонија

${ }^{2}$ Институт за фармацевтска хемија, Фармацевтски факултет, Универзитет “Св Кирил и Методиј”, Скопје, Македонија

${ }^{3}$ Клиника за неврологија, Медицински факултет, Универзитет “Св Кирил и Методиј”, Скопје, Македонија
\end{abstract}

Клучни зборови: карбамазепин, карбамазепин-10,11-епоксид, плазма, цврсто-фазна екстракција (SPE), HPLC, валидација

Карбамазепинот е најчесто употребуван антиепилептичен лек во третман на парцијални и генерализирани тонично-клонични напади. Карбамазепин-10,11-епоксидот е најзначаен метаболит на карбамазепинот, бидејќи е фармаколошки активна супстанција со антиконвулзивни особини. Според тоа, рутинската анализа на карбамазепим-10,11-епоксид заедно со карбамазепин, може да даде оптимални резултати во терапевтското следење на третманот со карбамазепин. 
Целта на овој труд е да се оптимизира и валидира едноставен и сигурен SPE-HPLC метод за истовремено определување на карбамазепин и неговиот главен метаболит, карбамазепин-10,11-епоксид во плазма, со цел да се добијат резултати со соодветен квалитет и сигурност со што ќе се обезбеди примена на предложениот биоаналитички метод во следење на терапевтските концентрации на карбамазепин и неговиот активен метаболит.

Екстракцијата на аналитите од примероците на плазма е изведена со помош на цврсто-фазна екстрактивна постапка. Разделувањето на екстрахираните аналити е спроведено на реверзно фазна колона со изократско елуирање со мобилна фаза составена од ацетонитрил и вода $(35: 65, \mathrm{v} / \mathrm{v})$, на температура од $30^{\circ} \mathrm{C}$. Детекцијата е изведена на бранова должина од $220 \mathrm{~nm}$.

Добиените вредности за приносот на екстракција се повисоки од $98 \%$ за сите аналити, определени во четири концентрациски точки од линеарниот концентрациски опсег. Воспоставениот метод покажува одлична селективност, осетливост, линеарност, прецизност и точност. Студиите за стабилност укажуваат дека работните раствори и примероците од плазма, чувани под различни услови, се стабилни во тек на целиот период потребен за изведување на анализите. Методот е успешно применет за определување на карбамазепин и карбамазепин-10,11-епоксид во плазма добиена од пациенти третирани со карбамазепин како монотерапија или во политерапија.

Како заклучок, воспоставениот биоаналитички метод е соодветен за примена во следење на терапевтските концентрации на карбамазепин и на неговиот активен метаболит, карбамазепин-10,11-епоксид, кај пациенти болни од епилепсија кои се под терапија со карбамазепин. 
